\title{
An Analysis of the Ecological Significance of Lifestyle Changes
}

\author{
Chunmei Shen \\ Jiangsu Ocean University, Lianyungang, China \\ Email: 447512457@qq.com
}

How to cite this paper: Shen, C.M. (2020) An Analysis of the Ecological Significance of Lifestyle Changes. Open Access Library Journal, 7: e6620.

https://doi.org/10.4236/oalib.1106620

Received: July 16, 2020

Accepted: August 16, 2020

Published: August 19, 2020

Copyright $\odot 2020$ by author(s) and Open Access Library Inc.

This work is licensed under the Creative Commons Attribution International License (CC BY 4.0).

http://creativecommons.org/licenses/by/4.0/ (c) (i)

Open Access

\begin{abstract}
With the development of economy and the increase of wealth, people's demand for beautiful ecological environment is increasingly prominent. Good life calls for ecological good, while ecological evil necessitates lifestyle change. Facing the ecological environment deterioration, human beings should pursue a new way of life, thinking about ecological requirements of people's new life attitude, impacts of lifestyle change on the production mode, the influence of the new life view on the relation between man and nature, so as to reshape the relationship between human and nature, and promote the harmonious development of man and nature.
\end{abstract}

\section{Subject Areas}

Development Economics, Ecology

\section{Keywords}

Lifestyle, Ecological Crisis, Life View, Value

\section{Introduction}

The lifestyle of modern people pursuing the maximization of material benefits has brought harm to the ecological environment, and the old lifestyle pursuing maximum consumption and material satisfaction has caused troubles to human beings and the ecological environment, thus hindering human development. The severe ecological environment and the sharp decline in the quality of life are the tragic consequences of the materialism, money worship and hedonism lifestyle that contemporary people choose, which also tells them that the lifestyle they choose is not suitable for sustainable development of human beings. Under the vigilance of ecological crisis, the consciousness of modern people to choose a new way of life is the basic way to solve the ecological crisis, and influence the 
life style. The way of life has a motile reaction. When people choose green, minimalist lifestyle, mode of production is subsequently changed. The production mode plundering natural resources will be turned into clean production mode, greatly reducing the environmental pollution and destruction, which has important significance for ecology. At the same time, it also alleviates the contradictory relationship between human and nature, and makes people realize that they are a member of nature. Only when the overall ecological environment operates well, can human beings develop continuously and harmoniously. Therefore, to realize the harmonious co-existence between human and nature, we must change the way of life and establish a new view of life.

This article discusses the value of good ecology for a good life in Section 2. Ecological evil of the necessity of lifestyle change under the pressure of ecological evil is analyzed in Section 3. Section 4 addresses the relationships between new life view and new mode of production, while the impacts of a new life view on the human-nature relationship are explored in Section 5.

\section{A Good Life Requires Good Ecology}

In the face of the deteriorating ecological environment, human beings are reflecting on what they have done. They are disappointed and worried about the polluted ecological environment and yearn for a good life in harmony with nature. Human beings can never stop chasing spiritual wealth. The beauty of nature also urges people to pursue a good life in harmony with nature, which requires human beings to change the current way of life and production, strive to restore the natural nature, and restore the integrity of ecology and self-initiative. Under the great threat of ecological crisis, human beings have infinite longing and expectation for the new state of nature. If they want to live a good life integrated with nature, they need to change the existing concept of life and take practical actions to change the harsh living environment.

The beauty of the natural environment brings spiritual pleasure and satisfaction to people, so that they are shocked and reflected on it. They abandon the original, crazy and material pursuit, and establish a new view of life, pursuing spiritual abundance, material minimalism, and the beauty of life in harmony between man and nature. Some people think that living a life of minimalism and returning to nature is a kind of backward life and a life contrary to the laws of historical development. Obviously, this is just looking at the development prospect of human society from the material perspective, but ignoring the real needs and pursuits of human life. Changing people's concept of life and rejecting excessive material needs will promote the harmonious, orderly and steady development of human beings and nature [1]. People's thoughts and concepts guide people's behaviors. If you want to live a good ecological life, you should consider from the perspective of people's life concepts. Life practice is what people are doing all the time, and it is also the origin of philosophical theories.

People's goal of improving ecological environment must be solved from 
people's life. Both theory and practice should be transferred to real life. People's behavior activities are all related to external natural changes and development, which has an important impact on ecological environment. The humanization of nature and the naturalization of man are dialectically unified. Only when people first "naturalizes" ourselves, can we ensure that the humanized nature belongs to us. The riddle of the Sphinx in Greek mythology leaves us the following message: if we do not know "what is human", human will perish; answer this question correctly and we will survive [2]. Therefore, in order to improve the ecological environment and live a life in harmony with nature, people should change their concept of life and establish a new concept of life, so as to fundamentally solve the ecological problems caused by human activities.

\section{Ecological Evil Necessitates Lifestyle Change}

When human footprints all over the earth, the nature has become humanized nature. How man treats nature depends on his attitude towards life, and what kind of life concept he has is what kind of ecological environment he has. From this, we can see that the outbreak of ecological crisis should not only find the causes from the nature, but should reflect from the human itself, the ecological crisis is essentially the crisis of human itself. The fact that material determines consciousness does not mean that consciousness is always in a subordinate position [3]. Different life concepts directly lead to different ways of life and production, and therefore have different demands on natural resources. The emergence of ecological crisis is entirely due to the different life concepts held by people.

In the modern age, the infinite desire for material interests, ruthless plunder of limited natural resources, lead to the outbreak of ecological crisis, ecological crisis outbreak also let human examine ourselves in different aspects, from the ecological crisis brought about by the various unfavorable factors in the choice of people's life idea, prompting the establishment of new view and was born. It is in transforming the object world that talent truly proves itself to be a kind of being. This kind of production is a kind of active life of human beings. It is through this production that nature becomes his work and his reality. Therefore, the object of labor is the objectification of the human-like life; Not only does man double himself spiritually, as he does in consciousness, but he does so actively and practically, and thus perceives himself in the world he creates [4]. Ecological crisis is the result of excessive transformation of nature by human beings. It is a catastrophic harm brought by human beings when they create material wealth for themselves. Ecological crisis can also verify the correctness of people's concept of life. The objective reality of ecological crisis shows that contemporary people need to change their current concept of life, establish environmental protection consciousness, pay attention to the existence of nature, and always bear in mind that destroying the balance of ecological environment is hindering the way of survival and development of human beings.

People cannot exist independently from nature. People are just the guardian 
of nature, not the conqueror over nature. Einstein explained the relationship between human beings and nature from the perspective of time and space. $\mathrm{He}$ thought that human beings were too concerned with ourselves and did not have an inclusive mind. We are part of the whole universe, but we are limited by time and space. As humans explore the self, they develop an "optical illusion" that their emotions and thoughts are different from those of other species. Under this illusion, humans confine themselves to their own desires and care only for those close to them. Only by opening up our emotions and embracing everything can we escape from this prison [5]. Human beings, like all natural things, are a part of the whole universe, and they have an inseparable relationship with nature. Human lifestyle change is bound to have impacts on the natural environment, and changes in the nature will affect people. This mutual effect requires a life view in line with natural humanity. The new life view stresses the spiritual aspects of life, advocates a resources saving lifestyle and pursue harmony between human beings and nature. This new life view will guide and affect the choice of the people's way of life, change the current way of production, and fundamentally solve the ecological crisis as well as the contradiction between man and nature.

\section{New Life View and New Mode of Production}

The historical materialist world view tells us that in order to create their own history, people must be able to live, and people must be able to engage in daily life activities and various social activities, first of all, to survive, to continue the generations. This requires food, clothing, housing and other materials of life, and how people make use of these materials, how to live, has formed the human unique way of life [6]. Under different historical conditions, people have different modes of production. The mode of production and the way of life are the two most basic forms of social activities in the development of human society. The difference of life attitude will lead to the choice of different life style. Therefore, the change of life attitude has a certain impact on the mode of production [7].

In contemporary society, life returns to us in the form of how we treat life. Treat life well and pursue a beautiful and harmonious life. Human beings will also get the pleasure and enjoyment brought by the beauty of life. Distorted life, excessive pursuit of material enjoyment, unable to restrain the desire of the control of human nature, human will live in the endless whirlpool of desire and unable to extrude, will face a short period of pleasure after the permanent emptiness and endless pain [8]. The quality of human life depends on how we face it and what we pursue it for. Faced with a series of realistic problems in the ecological environment caused by the lifestyle that contemporary people choose, people have to question themselves about what kind of life is a good life, change contemporary people's attitude towards life, and pursue a kind of beautiful life that is in harmony with nature and in accordance with human nature [9]. 
Faced with environmental problems, people began to think about how to change the stalemate between man and nature. When people from the craze for economy to yearn for the simple life, the pursuit of natural harmony will also promote the transition from the extensive economic growth mode to the mode of green production, thus greatly reducing the use of natural resources, and utilize the natural resources to the limit, which can not only meet the needs of the people's life, but also protect the natural resources, ecosystem and make the person and nature coexist peacefully.

\section{The New Life View Reshapes the Relationship between Man and Nature}

The so-called new life view is to abandon the original unreasonable one, which advocates material aspects and pays attention to personal interests and hinders the harmonious development between man and nature. The new view on life is the criticism and reflection of the bad consequences caused by the old one. While reviewing the ancient view on life in the East and the West, the green view on life established in the process of drawing lessons from the developed countries, and the old view on life, to realize the peaceful coexistence of man and nature. It shows that contemporary people attach great importance to the ecological environment and their pursuit of a good life, which will effectively react on people's life style, affect the change of production mode, promote people's living standard and maintain the balanced cycle of ecological development.

As a form of social existence, life style determines and dominates the formation of people's concept of life, which is the reflection of social life in human brain and can guide people's life behavior and production mode. Ecological crisis alert on ideology for modern people to establish new life view, pay attention to the change of the ecological environment, the people's production and living with nature consistency, always remember to people is a part of nature, whether people's actions to run according to the quasi, defies the laws of could not only to satisfy people's desire and unruliness [10]. The new view on life pursues a kind of beauty in harmony with nature, which requires contemporary people to fully realize the inseparability between human and nature, and fully enjoy the incredible beauty presented by nature, which is the beautiful life that contemporary people should pursue [11].

The new way of life we have chosen and the new view on life advocate that, on the one hand, we should improve the ability of human beings to transform nature with a positive attitude and meet people's needs for material life; On the other hand, it is to limit human desires within a certain range and not indulge them to plunder natural resources uncontrollably [12]. As Marx pointed out, the transformation of matter between man and nature should be reasonably regulated and carried out under conditions most worthy and most suitable to human nature. At the same time, we should pay attention to the improvement of people's spiritual realm, improve people's moral cultivation, improve ourselves 
in spirit, and make people friendly [13]. The improvement of people's spiritual realm is conducive to the transformation of people's ideological concepts. When people realize the inseparability between human and nature, they will choose a lifestyle in harmony with nature, hoping to live a good life in harmony with nature [14].

\section{Conclusion}

Since the Industrial Revolution, the relationship between man and nature has deteriorated with the development of production technology, and human development has been impeded in the face of the deteriorating ecological environment. Therefore, it is necessary to reflect on whether the way of life chosen by contemporary people is in line with the modern requirements and conducive to the sustainable development of man and nature [15]. Modern people are required to establish a new life view in order to reshape the relationship and maintain the harmony between man and nature. This article recovers the value of lifestyle and life view for social change. Different from more macro discussions in the current development literature, this article explores the micro relationship between life and development and deems that, to a great extent, the development mode change starts from lifestyle change. Since this article discusses the theoretical relationships between a new life view and the production mode, more work still needs to be done to explore empirical aspects of this relationship and the institutional arrangements promoting lifestyle.

\section{Conflicts of Interest}

The author declares no conflicts of interest regarding the publication of this paper.

\section{References}

[1] Giddens (2011) Consequences of Modernity. Tian, H. (Trans.), Yilin Press, Nanjing, 72-75.

[2] Badiou (2019) What Is Real Life. Lan, J. (Trans.), Renmin University of China Press, Beijing, 49.

[3] Xu, Q. (2004) Selected Readings of Marx’s Classics. Jiangsu People's Publishing House, Nanjing, 17.

[4] Marx (2000) Economic and Philosophical Manuscripts of 1844. People's Publishing House, Beijing, 58.

[5] Einstein (1977) The Einstein Anthology. Fan, D., et al. (Trans.), Commercial Press, Shanghai, 136.

[6] Zhang, Y. (2016) Back to Marx. Jiangsu People's Publishing House, Nanjing, 248.

[7] Tao, H. (2012) Ecological Practice. People’s Publishing House, Beijing, 156-157.

[8] Rice, W. (1993) The Control of Nature. Chongqing Press, Chongqing, 104-105.

[9] Foster (2006) Ecological Crisis and Capitalism. Shanghai Translation Publishing House, Shanghai, 85.

[10] Yin, S. (1998) On Ecological Needs. Guangming Daily, 26 January 1998. 
[11] Maester, C. (1999) Natural Death. Jilin People's Publishing House, Changchun, 205-207.

[12] Yu, M. (2000) Ecological Philosophy. Shaanxi People’s Education Press, Xi'an, 61.

[13] Fan, H. (2001) Ecological Rationality of Contemporary Ethical Spirit. Chinese Social Science, No. 1, 24-34+205.

[14] Owen, L. (1985) The Coming Age of Human Ecology. Social Science Abroad, 10.

[15] Saxe, H. (1991) Ecological Philosophy. Oriental Press, Beijing, 152. 